\title{
STUDI RESIKO KERJA OPERATOR LABORATORIUM PENGUJIAN AIR DENGAN MENGGUNAKAN METODE QEC (QUICK EXPOSURE CHECK) (STUDI KASUS PT. SUCOFINDO BATAM)
}

\section{THE STUDY OF OPERATOR WORK RISK AT WATER TESTING LABORATORY WITH QEC METHOD (QUICK EXPOSURE CHECK) (A CASE STUDY : PT SUCOFINDO BATAM)}

\author{
Benedikta Anna Haulian Siboro ${ }^{1}$, Surifto ${ }^{2}$ \\ ${ }^{12}$ Program Studi Teknik Industri, Universitas Riau Kepulauan \\ Batam, Indonesia \\ 1b.anna79@gmail.com, 22urifto@yahoo.com
}

\begin{abstract}
Abstrak
Laboratorium PT Sucofindo Batam memiliki laboratorium pengujian yang berkaitan dengan mutu dalam hubungannya dengan keselamatan, keandalan dan kinerja produk atau kualitas material. Salah satu pengujian yang dilakukan di laboratorium ini adalah pengujian air. Pekerjaan ini dilakukan dengan cara manual dan berulang ulang dalam posisi berdiri yang dilakukan selama rata-rata 8 jam kerja dengan 1 jam istirahat setelah 4 jam bekerja. Penelitian ini bertujuan untuk menganalisa fasilitas kerja yang ada di laboratorium pengujian air dengan pendekatan Quick Exposure Check (QEC) di PT.Sucofindo Batam. Pengumpulan data dilakukan dengan studi lapangan, wawancara terhadap pekerja, dan kuesioner. Output yang didapat berupa total exposure level dari skor 4 bagian tubuh. Hasil penelitian menunjukkan bahwa terdapat keluhan pada bagian punggung, bahu dan leher dikarenakan proses kerja yang membungkuk. Selain itu hasil QEC menunjukkan $\geq 50 \%(61,32 \%)$ yang artinya perlu tindakan (action) yang harus diambil yaitu perbaikan fasilitas kerja guna mengurangi keluhan dan kelelahan akibat kerja.
\end{abstract}

Kata Kunci : laboratorium pengujian air, keluhan, kelelahan, QEC

\begin{abstract}
The Laboratory of PT Sucofindo Batam has testing laboratories that related with quality in relation to safety, reliability and product performance or material quality. One of the tests conducted in this laboratory is water testing. This work is done manually and repeatedly in a standing position performed for an average of 8 hours of work with 1 hour of rest after 4 hours of work. The purpose of this research is to analyze existing work facilities in water testing laboratory with Quick Exposure Check (QEC) approach in PT.Sucofindo Batam. Data collection was done by field study, interview to workers, and questionnaire. Output obtained in the form of total exposure level of score of 4 body parts. The results showed that there are complaints on the back, shoulders and neck due to work processes that bend. In addition QEC results show $\geq 50 \%(61.32 \%)$ which means need action that must be taken to improve the work facilities to reduce complaints and fatigue due to work.
\end{abstract}

Keywords: water testing laboratory, complaints, fatigue, QEC 


\section{PENDAHULUAN}

Kinerja seorang operator dapat dipengaruhi oleh kondisi dari stasiun kerja tempat operator tersebut melakukan aktivitas kerjanya. Kondisi yang diharapkan dari stasiun kerja ataupun lingkungan kerja yang baik bagi seorang operator tentunya adalah kondisi yang efektif, nyaman, aman, sehat, dan efisien. Pada umumnya seseorang operator yang bekerja dengan pergerakan yang berulang-ulang secara terus menerus, pergerakan postur tubuh yang tidak baik, dan penggunaan sejumlah kekuatan yang diperlukan pada suatu aktivitas secara belebihan dapat mengalami cedera berupa gangguan otot rangka (musculoskeletal disorder).

Pada umumnya seseorang operator yang bekerja dengan pergerakan yang berulangulang secara terus menerus, pergerakan postur tubuh yang tidak baik, dan penggunaan sejumlah kekuatan yang diperlukan pada suatu aktivitas secara belebihan dapat mengalami cedera berupa gangguan otot rangka (musculoskeletal disorder).

Berdasarkan wawancara kepada operator laboratorium pengujian air bahwa operator mengeluh pegal-pegal pada leher dan juga punggung. Berdasarkan hal tersebut, perlu dilakukan Usulan perbaikan sistem kerja tersebut berdasarkan hasil analisis dari metode Quick Exposure Check (QEC).

\section{Ergonomi}

Ergonomi berasal dari bahasa Yunani yaitu Ergon yang berarti kerja dan Nomos yang berarti hukum dan dapat didefinisikan sebagai studi tentang aspek-aspek manusia dalam lingkungan kerjanya dan akan mempelajari keterbatasan dari kemampuan manusia dalam berinteraksi serta mempelajari peralatan atau perangkat buatan (Sholihah \& Anward, 2012). Tujuan ergonomi adalah untuk menambah efektivitas penggunaan objek fisik dan fasilitas yang digunakan oleh manusia, dan merawat atau menambah nilai tertentu yang layak misalnya kesehatan, keselamatan, kenyamanan, kepuasan pada proses penggunaan tersebut. Ruang lingkup ergonomi meliputi teknik, fisik, pengalaman psikis, anatomi, antropometri, sosiologi, fisiologi, desain dan lain-lain (Sholihah, 2013) yang cakupan ini termasuk dalam penelitian ergonomi yang dilakukan oleh banyak penelitian (Santoso, Siboro, \& Annisa Purbasari, 2014)

Dalam aplikasinya, penerapan ergonomi dapat ditemui dalam kehidupan sehari seperti posisi kerja, proses kerja, tata letak tempat kerja, mengangkat dan lain-lain. Sering kali pada saat beraktivitas ditemukan ketidaksesuaian mesin, alat kerja atau produk dengan penggunannya yang tidak hanya berdampak pada ketidaknyamanan, tetapi juga berdampak pada hal lainnya seperti 
kerja otot yang berlebihan, produktivitas menurun, resiko kesalahan kerja, keluhan pegal dan ngilu serta kelelahan pada bagian sistem otot-rangka jika penggunaannya dilakukan dalam waktu lama(Irdiastadi \& Yassierli, 2014). Kelelahan yang berkepanjangan akan mengakibatkan rusaknya jaringan tubuh antara lain cedera pada sendi, saraf, tendon, otot, ligament, sendi, tulang rawan, tulang cakram belakang dan jaringan neurovaskular atau istilah umumnya disebut dengan gangguan MSDs (Musculoskeletal Disorders).

\section{Musculoskeletal Disorders (MSDs)}

Musculoskeletal disorders (MSDs) atau gangguan otot rangka merupakan kerusakan pada otot, saraf, tendon, ligament, persendian, kartilago, dan discus invertebralis. Kerusakan pada otot dapat berupa ketegangan otot, inflamasi, dan degenerasi. Sedangkan kerusakan pada tulang dapat berupa memar, mikro faktur, patah, atau terpelintir. MSDs terjadi dengan dua cara:

1. Kelelahan dan keletihan terus menerus yang disebabkan oleh frekuensi atau periode waktu yang lama dari usaha otot, dihubungkan dengan pengulangan atau usaha yang terus menerus dari bagian tubuh yang sama meliputi posisi tubuh yang statis;

2. Kerusakan tiba-tiba yang disebabkan oleh aktivitas yang sangat kuat/berat atau pergerakan yang tak terduga. Frekuensi yang lebih sering terjadi MSDs adalah pada area tangan, bahu, dan punggung.

\section{Quick Exposure Check ( QEC)}

Quick Exposure Check (QEC) merupakan suatu metode untuk penilaian terhadap resiko kerja yang berhubungan dengan gangguan otot di tempat kerja. Metode ini menilai gangguan resiko yang terjadi pada bagian belakang punggung, bahu/lengan, pergelangan tangan, dan leher QEC membantu untuk mencegah terjadinya WMSD's seperti gerak repetitive, gaya tekan, postur yang salah, dan durasi kerja (Stanton, Hedge, Brookhuis, Salas, \& Hendrick, 2005).

Konsep dasar dari metode ini sebenarnya adalah mengetahui seberapa besar exposure score untuk bagian tubuh tertentu dibandingkan dengan bagian tubuh lainnya. Exposure score dihitung untuk masing- masing bagian tubuh seperti pada punggung, bahu/lengan atas. Salah satu karakteristik yang penting dalam metode ini adalah penilaian dilakukan oleh peneliti dan pekerja, dimana faktor risiko yang ada dipertimbangkan dan digabungkan dalam implementasi dengan tabel skor yang ada. Implementasi dari QEC tersebut meliputi, worksheet dari pengamat 
dan dari operator, data berupa gambar dan video, tabel QEC, kemudian perhitungan Exposure skor. Dari Worksheet yang nantinya sudah diwawancarai dan diisi oleh pengamat dan operator, maka selanjutnya hasil worksheet di konversikan ke tabel exposur yang terdiri dari penilaian, punggung, bahu, pergelangan tangan dan leher. Berikut dibawah tabel exposur skor;

Tabel 1. Exposure Score

\begin{tabular}{ccccc}
\hline & \multicolumn{3}{c}{ Exposure Score } \\
\cline { 3 - 5 } Score & Rendah & Sedang & Tinggi & Sangat Tinggi \\
\cline { 3 - 5 } Punggung (statis) & $8-15$ & $16-22$ & $23-29$ & $29-42$ \\
Punggung(bergerak) & $10-20$ & $21-30$ & $31-40$ & $41-56$ \\
Bahu/Lengan & $10-20$ & $21-30$ & $31-40$ & $41-56$ \\
Pergelangan Tangan & $10-20$ & $21-30$ & $31-40$ & $41-46$ \\
Leher & $4-6$ & $8-10$ & $12-14$ & $16-18$ \\
\hline
\end{tabular}

Tabel 1. menunjukkan 4 bagian tubuh yaitu punggung (statis), punggung (bergerak), bahu/lengan, pergelangan tangan, dan leher.

Tabel 2. Action level

\begin{tabular}{|c|c|c|}
\hline Jumlah skor & $\begin{array}{l}\text { Action } \\
\text { level }\end{array}$ & Penanganan \\
\hline $\begin{array}{l}\text { Kurang dari } \\
70\end{array}$ & level 1 & Nilai tersebut dapat diterima \\
\hline $70-88$ & level 2 & Investigasi lebih lanjut \\
\hline $89-123$ & level 3 & $\begin{array}{l}\text { Investigasi lebih lanjut dan dilakukan penanganan dalam } \\
\text { waktu dekat }\end{array}$ \\
\hline $\begin{array}{l}\text { Lebih dari } \\
123\end{array}$ & level 4 & Investigasi lebih lanjut dan dilakukan penanganan scepatnya \\
\hline
\end{tabular}

Selanjutnya, dari hasil skor yang telah didapat dari skor penelitian Quick Exposure Checklist (QEC) diatas, maka selanjutnya dapat juga dilakukan penentuan exposure score untuk tubuh yang telah diteliti (Tabel 2). Total skor untuk area tubuh ditentukan dari interaksi antara exposure level untuk faktor sakit di tubuh yang relevan dan faktor - faktor lainnya. Faktor - faktor tersebut adalah sebagai berikut :

Tabel 3 Faktor QEC

\begin{tabular}{llll}
\multicolumn{1}{c}{ Punggung } & \multicolumn{1}{c}{ Bahu/Lengan } & \multicolumn{1}{c}{ Tangan/Pergelanga } & \multicolumn{1}{c}{ Leher } \\
& & Kekuatan & Durasi \\
Beban berat & Beban berat & Durasi & Postur \\
Durasi & Durasi & Frekuensi pergerakan & Permintaan visual \\
$\begin{array}{l}\text { Frekuensi } \\
\text { Pergerakan }\end{array}$ & Berat tugas & & \\
Postur & Frekuensi pergerakan & Postur & \\
\hline
\end{tabular}


Hasil dari perhitungan tabel exposure score ini kemudian akan digunakan untuk menghitung nilai exposure level menggunakan rumus:

$$
\mathrm{E}(\%)=\frac{\mathrm{X}}{\mathrm{Xmax}} 100 \%
$$

$\mathrm{X}=$ Total skor yang didapat untuk paparan risiko cedera untuk punggung,bahu/lengan, pergelangan tangan, dan leher yang diperoleh dari perhitungan $\mathrm{X}$ max = Total maksimum skor untuk paparan yang mungkin terjadi untuk punggung, bahu/lengan, pergelangan tangan, dan leher. Xmax adalah konstan untuk tipe - tipe tugas tertentu. Pemberian skor maximum ( $\mathrm{Xmax}=162$ ) apabila tipe tubuh adalah statis, termasuk duduk atau berdiri tanpa pengulangan ( repetitive ) yang sering dan penggunaan tenaga/beban yang relatif lebih rendah. Untuk pemberian skor maximum ( $X \max =178$ ) apabila melakukan material handling yaitu mengangkat, mendorong, menarik dan membawa beban.

Setelah menghitung exposure level dari rumus Exposur (E), kemudian untuk menentukan tindakan apa yang dilakukan berdasarkan dari hasil perhitungan total exposure score. Tindakan yang harus diambil berdasarkan nilai yang dihasilkan dalam perhitungan exposure level dapat dilihat pada Tabel berikut:

Tabel 4 Action Level QEC

\begin{tabular}{cc}
\hline Total Exposure Level & \multicolumn{1}{c}{ Action } \\
\hline$<40 \%$ & Aman \\
$40-49 \%$ & Perlu penelitian lebih lanjut \\
$50-69 \%$ & $\begin{array}{l}\text { Perlu penelitian lebih lanjut dan dilakukan } \\
\text { perubahan } \\
\text { Dilakukan penelitian dan perubahan secepatnya }\end{array}$ \\
\hline $70 \%$ & .
\end{tabular}

\section{METODOLOGI}

Dalam penelitian ini, penulis mengambil objek penelitian berupa stasiun uji laboratorium dengan menggunakan metode Quick Exposure Check (QEC) pada departemen Uji sampel Laboratorium PT.SUCOFINDO yaitu metode suatu metode untuk penilaian terhadap resiko kerja yang berhubungan dengan gangguan otot di tempat kerja. Metode ini menilai gangguan risiko yang terjadi pada bagian belakang punggung, bahu/lengan, pergelangan tangan, dan leher. Selain metode QEC, didistribusikan juga kuisioner untuk mengetahui area keluhan dari pekerja laboratorium.

\section{PEMBAHASAN}


Berikut ini adalah kondisi aktual pekerja pada stasiun pengujian air pada laboratorium:

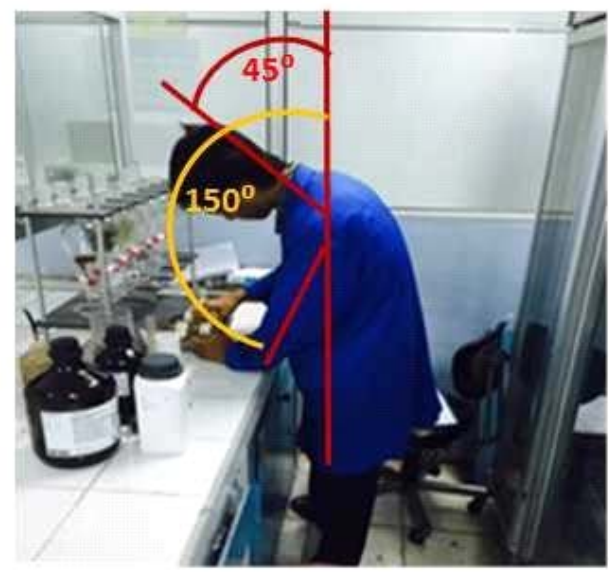

Gambar 1 Proses pengujian air pada laboratorium

Berdasarkan gambar aktual posisi berdiri pekerja dengan pungggung membentuk sudut $45^{\circ}$, kaki tidak berdiri tegak dan tangan membentuk sudut $150^{\circ}$, kepala juga menunduk yang mengakibatkan kelelahan pada bagian leher, bahu, pinggang, punggung serta tangan. Hal ini jika dilakukan berulang kali dapat mengakibatkan penyakit akibat kerja yang berasal dari sikap postur kerja yang tidak ergonomis karena tidak adanya fasilitas kerja yang tidak sesuai dengan antropometri pekerja.Operator seharusnya bekerja dalam posisi berdiri tegak, dengan lengan atas dalam posisi santai dan dalam posisi vertikal dengan yang dekat dengan meja, dan dengan bawah inklinasi ( dimiringkan sedikit ) dari kedudukan horizontal. Hal ini dapat dicapai jika ketinggian tempat kerja kira - kira $5 \mathrm{~cm}$ dibawah tinggi siku operator (Nurmianto, 1996). Dalam menentukan posisi tubuh dalam bekerja sangat ditentukan oleh jenis pekerjaan yang diilakukan. Menurut Iriastadi dan Yassierli (2014) stasiun kerja yang mengharuskan operator berdiri tidak begitu disukai, tetapi seirng kali diperlukan.Terutama untuk pekerjaan dengan kondisi sebagai berikut:

a. Pekerjaan membutuhkan penanganan barang/material yang sering, apalagi jika materialnya berat

b. Pekerjaan membutuhkan aktivitas menjangkau

c. Pekerjaan membutuhkan mobilitas yang cukup tinggi, misalnya berpindah di sekitar stasiun kerja. 


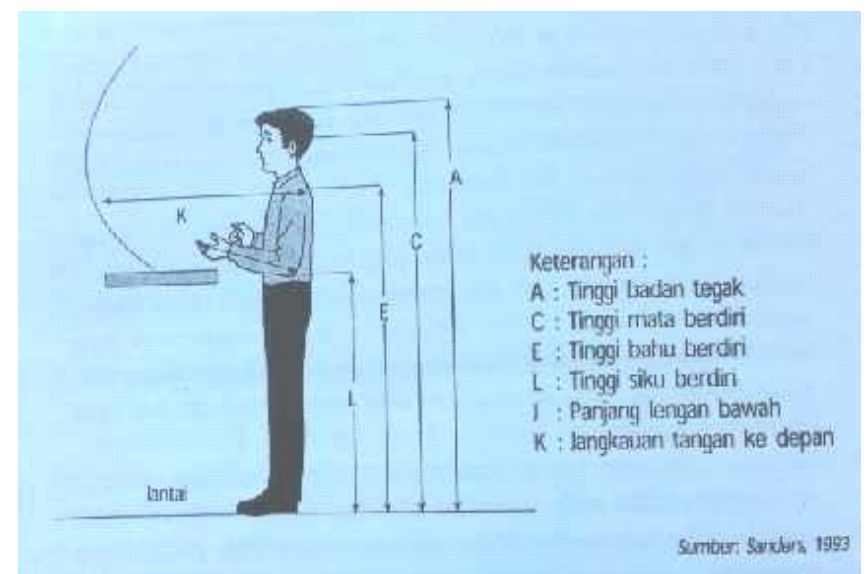

Gambar 2 Posisi kerja berdiri

Dalam perancangan meja kerja dengan prinsip stasiun kerja berdiri, dimensi - dimensi kritis pada gambar 2 perlu diperhatikan meliputi : tinggi siku berdiri, jangkauan tangan, rentangtangan. Menurut Pulat dan Clark (Tarwaka, 2011) memberikan pertimbangan tentang pekerjaan yang paling baik dilakukan posisi berdiri yaitu :

a. Tidak tersedia tempat untuk kaki dan lutut

b. Harus memegang obyek yang berat ( lebih dari 4,5 kg )

c. Sering menjangkau keatas kebawah dan kesamping

d. Sering dilakukan pekerjaan dengan menekan kebawah

e. Diperlukan mobilitas yang tinggi

Berdasarkan hasil wawancara oleh 3 orang operator yaitu ketidaknyamanan bekerja yang dirasakan oleh operator berupa keluhan nyeri pada tangan, punggung, leher dan bahu, ketidaknyamanan fasilitas kerja meja kerja yang kurang tinggi dan diperlukan perbaikan secepatnya dan perlunya merancang meja dengan prinsip kerja berdiri.

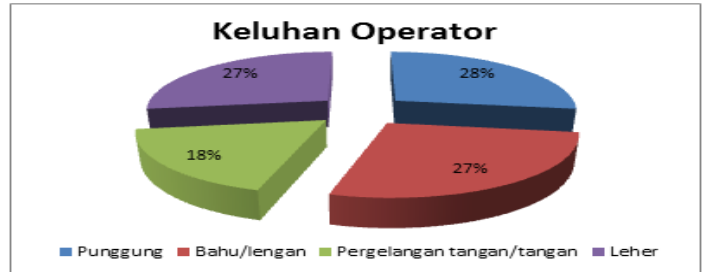

Gambar 3 Grafik keluhan operator laboratorium pengujian Air

Pada Grafik dan tabel diatas, keluhan pada postur kerja yang membungkuk memiliki nilai persentase dan grafik yang sama adalah pada bagian punggung, bahu/ lengan dan leher $27 \%$ sedangkan pergelangan tangan hanya $18 \%$. 


\section{Sikap dan Postur Tubuh dari Hasil QEC}

Berdasarkan pengamatan dan hasil kuesioner dan wawancara,didapat dari 3 orang mengalami keluhan pada 4 bagian tubuh dan otot, maka didapatkan persentase resiko gangguan otot pada proses ini adalah sebagai berikut :

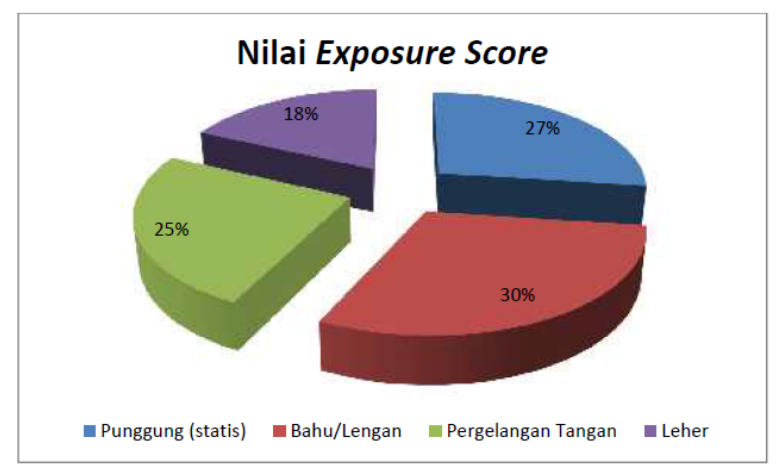

Gambar 4. Grafik Persentase skor QEC

Grafik diatas menjelaskan bahwa untuk skor lengan/bahu 30\%, punggung 27\%, pergelangan tangan $25 \%$ dan leher $18 \%$ berada pada level very high. Hal ini berkaitan dengan posisi membungkuk yang berulang - ulang. Cara seperti itu sangatlah beresiko cidera kerja yang cukup tinggi. Selanjutnya, nilai Exposure level berdasarkan nilai $\mathrm{X}$ max, Xmax adalah konstan untuk tipe - tipe tugas tertentu. Pemberian skor maximum ( Xmax = 162 ) apabila tipe tubuh adalah statis, termasuk duduk atau berdiri tanpa pengulangan ( repetitive ) yang sering dan penggunaan tenaga/beban yang relatif lebih rendah. Untuk pemberian skor maximum ( $\mathrm{Xmax}=178$ ) apabila melakukan material handling yaitu mengangkat, mendorong, menarik dan membawa beban.

Tabel 5 Perhitungan Persentase Exposure check

\begin{tabular}{|c|c|c|}
\hline Pekerja & Perhitungan Exposure & Hasil Exposure \\
\hline 1 & $\mathrm{E} \%=104 / 178 \times 100 \%=0.84$ & $64.20 \%$ \\
\hline 2 & $\mathrm{E} \%=94 / 178 \times 100 \%=0.75$ & $58.02 \%$ \\
\hline 3 & $\mathrm{E} \%=100 / 178 \times 100 \%=0.67$ & $61.73 \%$ \\
\hline
\end{tabular}

Dari hasil tersebut terlihat bahwa semua operator pengujian air memiliki hasil Exposure score $\geq 50 \%$ yaitu perlu penelitian lebih lanjut dan dilakukan perubahan. Perubahan yang dilakukan dapat saja berupa perbaikan fasilitas kerja (meja kerja) sehingga dapat mengurangi kelelahan dan keluhan akibat kerja. 


\section{KESIMPULAN}

Dari hasil penelitian ini, bahwa dapat disimpulkan bahwa fasilitas kerja yang digunakan tidak sesuai postur tubuh operator sehingga mengakibatkan kelelahan dan keluhan pada area punggung, bahu dan leher. Hal ini diperkuat juga dengan hasil QEC yang menunjukkan nilai QEC $\geq 50 \%$ (rata-rata 61,32\%) yang artinya perlu dilakukan penelitian dan perbaikan guna mengurangi keluhan akibat kerja.

\section{DAFTAR PUSTAKA}

Irdiastadi, H., \& Yassierli. (2014). Irdiastadi_Yassierli_Ergonomi Suatu Pengantar.pdf. (Nia, Ed.). Bandung: PT Remaja Rosdakarya.

Nurmianto, E. (1996). Nurmianto_Konsep Dasar dan Aplikasinya.pdf. (I. K. Gunarta, Ed.). Jakarta: PT.Candimas Metropole.

Santoso, A., Siboro, B. A. H., \& Annisa Purbasari. (2014). Memenuhi Standar Pengukuran. Profisiensi, 2(2), 81-91. http://journal.unrika.ac.id/index.php/jurnalprofisiensi/article/view/317/293

Sholihah, Q. (2013). Sholihah_Ergonomi dan Keselamatan Kerja.pdf. Surabaya: Pusat Penerbitan dan Percetakan Unair (Aup).

Sholihah, Q., \& Anward, H. H. (2012). Sholihah_Anward-Ergonomika dan Faktor Manusia.pdf. Yogyakarta: Nusa Media.

Stanton, N., Hedge, A., Brookhuis, K., Salas, E., \& Hendrick, H. (2005). Handbook of Human Factors and Ergonomics Methods. Handbook of Human Factors and Ergonomics Methods. London: CRC Press. https://doi.org/10.1201/9780203489925

Tarwaka. (2011). Tarwaka_Ergonomi Industri.pdf. Surakarta: Harapan Press. 